PNL-7659

UC-350

\title{
A Tool for Estimating the Mix of Energy Conservation Measures Given Competing Acquisition Scenarios
}

R. W. Schultz

March 1991

Work supported by the

Bonneville Power Administration

under a Related Services Agreement

with the U.S. Department of Energy

Contract DE-AC06-76RLO 1830

Pacific Northwest Laboratory

Operated for the U.S. Department of Energy

by Battelle Memorial Institute 


\title{
DISCLAIMER
}

This report was prepared as an account of work sponsored by an agency of the United States Government. Neither the United States Government nor any agency thereof, nor Battelle Memorial Institute, nor any of their employees, makes any warranty, expressed or implied, or assumes any legal liability or responsibility for the accuracy, completeness, or usefulness of any information, apparatus, product, or process disclosed, or represents that its use would not infringe privately owned rights. Reference herein to any specific commercial product, process, or service by trade name, trademark, munufacturer, of otherwise does not necessarily constitute or imply its endorsement, recommendation, or favoring by the United States Government or any agency thereof, or Battelle Memorial Institute. The views and opinions of authors expressed herein do not necessarity state or reflect those of the United States Government or any agency thereof.

\author{
PACIFIC NORTHWEST LABORATORY \\ operated by \\ BATTELLE MEMORIAL INSTITUTE \\ for the \\ UNITED STATES DEPARTMENT OF ENERGY \\ under Contract DE-ACO6-76RLO 1830
}

Printed in the United States of America

Available to DOE and DOE contractors from the

Office of Scientific and Yechnical Information, P.O. Box 62, Oak Ridge, IN 37031; prices available from (615) 576-8401. FTS 626-8401.

Available to the public from the National Jechnical Information Service, U.S. Department of Commerce, 5285 Port Royal Rd., Springfield, VA 22161. 
PNL-7659

UC -350

\section{A TOOL FOR ESTIMATING THE MIX OF ENERGY CONSERVATION MEASURES GIVEN COMPETING ACQUISITION SCENARIOS}

R. W. Schultz

March 1991

Work supported by the Bonneville Power Administration under a Related Services Agreement with the U.S. Department of Energy Contract DE-AC06-76RLO 1830

Pacific Northwest Laboratory Richland, Washington 99352 



\section{EXECUTIVE SUMMARY}

To support the analysis work of the Bonneville Power Administration's Resource Program Environmental Impact Statement, analysts needed the ability to quickly and easily evaluate the effect of the energy conservation measure (ECM) mix and the amount of equipment/technology that could be replaced if they were adopted, given an alternative regional forecast of electricity savings potential. A toor called ECMMIX was developed in response to this need. A base-case forecast was provided by BPA to serve as a point of departure for the alternative forecasts, and a base-case ECM mix was estimated from the base-case forecast of regional megawatt savings. In addition, equipment and technology that could be replaced by the adoption of the ECM mix can be calculated. When alternative forecasts of regional savings are under consideration, ECMMIX is capable of calculating a new set of estimates for the associated ECM mix and the equipment replaced. A table demonstrating ECMMIX resuits is included. 


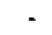

\section{-}




\section{CONTENTS}

EXECUTIVE SUMMARY

1.0 INTRODUCTION

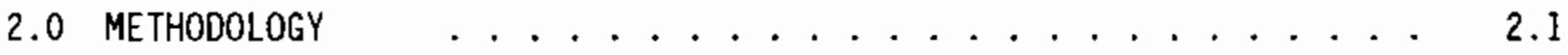

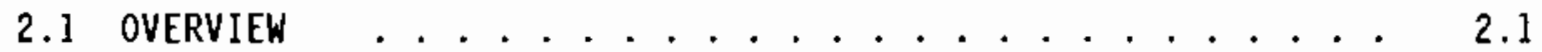

2.2 ECMMIX DEVELOPMENT . . . . . . . . . . . . . . . . 2.3

2.2.1 Split Composite Measures . . . . . . . . . . 2.3

2.2.2 ADM ECMS ................... 2.4

2.2.3 Line Item Adjustments . . . . . . . . . . . . 2.5

2.2.4 Measure Consolidation ............. 2.5

2.2.5 Renovation and Remodel Measures . . . . . . . . 2.6

2.2.6 Estimation of ECM Mix ............ 2.7

3.0 ECMMIX USER GUIDE . . . . . . . . . . . . . . 3.1

3.1 USER CAPABILITIES . . . . . . . . . . . . . . . 3.1

3.2 CONCLUSIDNS . . . . . . . . . . . . . . . . . . 3.4

4.0 REFERENCES . . . . . . . . . . . . . . . . . . . . . . 4.1

APPENDIX A - ADM REFRIGERATION ECMS . . . . . . . . . . . . . A.I

APPENDIX B - ECOTOPE REMODEL AND RENOVATIDN ECMS . . . . . . . . . . . B. 1

APPENDIX C - ECMS PER PROTOTYPICAL BUILDING . . . . . . . . . . C.1 
$+$

-

.

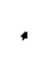




\subsection{INTRODUCTION}

Bonneville Power Administration (BPA) is conducting analyses that are to serve the Resource Program Environmental Impact Statement (RP/EIS). Parts of the RP/EIS are to address the impacts of commercial sector electricity conservation acquisitions under various conservation acquisition alternatives. These impacts include the energy conservation measure (ECM) mix adopted by the commercial sector and the equipment/technology that would be replaced by implementing new ECMs.

The goal of this project was to develop a tool that has the capability to detail region-wide numerical estimates of the commercial sector ECM and replaced technology mix. The tool (hereafter called ECMMIX) was to be sufficiently flexible and "user friendly" that analysts could easily perform sensitivity tests of alternative forecasts of energy conservation acquisitions. It needed to have the capability to assess impacts across different building types, utility regions, vintage and end-use categories, as well as to aggregate similar ECMs across all categories. The aggregation capability was to exist for the replaced technology as well.

The BPA provided al1 the necessary data for the analysis. The regional commercial sector conservation acquisition data for this analysis were obtained from BPA's resource analysis models, which are being used to project resource acquisitions for the RP/EIS alternatives. The ECM data is based primarily on DOE-2 Commercial Building Prototype Review and Revision, an analys is of ten commercial building types completed for BPA by United Industries Corporation (UIC 1987, 1988). Results from two other studies are incorporated into BPA's commercial sector conservation supply estimates. These studies are Commercial Refrigeration Resource Assessment by ADM Associates, Inc. (Wikler and ATereza 1988), and Lost Conservation Opportunities Created by Remodeling and Renovation in the Commercial Sector by Ecotope (Katz, Baylon \& Gordon 1989).

There are several considerations that add complexity to ECMMIX development. First, the UIC building prototypes that account for the majority of conservation potential are based on a mix of building categories that differ 
somewhat from building-type definitions in BPA's commercial load forecast, the source for BPA's commercial floorspace and electricity fuel share data. Second, the ECMs related to the ADM and Ecotope studies are not tied to specific, identifiable measures in the same way as the UIC measures. Third, adjustments to forecasted savings must be reversed for measures that are considered fuel-sensitive and have had line-loss credits applied to them, so as not to overestimate the number of ECMs associated with any particular savings forecast.

Chapter 2 presents specific details about the methodology and assumptions adopted in developing ECMMIX. Included is a discussion of data disaggregation, adjustments to forecasted savings estimates, and incorporation of ADM and Ecotope ECMs. Chapter 3 contains a user's guide to ECMMIX and concluding comments. 


\subsection{METHODOLOGY}

This chapter describes the methodology adopted for the development of ECMMIX. Included are data specifics and a discussion of assumptions and problem resolutions.

\subsection{OVERVIEW}

The ECMMIX tool and its estimating capabilities evolved out of a basecase conservation-acquisition scenario. The data for the base case correspond to BPA's high-load case scenario detailed in Draft 1990 Conservation Resource Supply Document (BPA 1990), and represent an accelerated and higher level of resource acquisition relative to no action. As discussed in the introduction, data for individual ECMs were obtained from the UIC, ADM, and Ecotope studies.

Base-case conservation acquisitions consist of individual ECM savings specific to a building type, utility region, vintage, timing opportunity, and end-use category. Relevant data for each line-item ECM include the size of the applicable prototypical building, the percentage of applicable floorspace serviced by electricity exclusively, a savings rate, and the regional savings potential. The savings rate reflects the potential kWh savings per thous and square feet (TSF). Each savings-rate value incorporates, among other things, adjustments for fuel-share sensitivities and line-loss credits. The regional savings potential represents the average megawatts of electricity savings that a line-item ECM would contribute under a high-load case scenario. Specifics regarding the procedure followed to obtain regional savings potential can be found in Draft 1990 Conservation Resource Supply Document (BPA 1990).

The objective of ECMMIX is to estimate the number of ECMs and the amount of replaced technology that correspond to a forecasted regional savings potential. The basic approach to meeting this objective is to multiply the savings rate per TSF by the prototypical building floorsize, which results in a savings rate per building type. Next, the regional savings potential is converted to kWhs by applying a conversion factor of $8.76 \mathrm{E} 6$. Dividing this regional savings potential value by the savings rate per building yields an 
estimate of the number of buildings corresponding to the savings potential. The number of ECMs that is applicable to each building type is provided by the ECM studies and, when applied to the number of buildings, produces an estimate of the number of ECMs needed to achieve the forecasted savings potential. Also available from the ECM studies is the technology/equipment replaced when a single ECM is adopted. With this information the replaced technology can be computed directly.

A critical category of the ECMs is the timing opportunity. Timing opportunity includes categories called lost opportunity, discretionary, remodel, and renovation. Lost opportunities correspond to ECMs that can be adopted only during construction or when a building undergoes major renovation and/or remodeling. Most remodel and renovation opportunities are associated with Ecotope ECMs and can be considered lost opportunities; however, their unique identification is maintained so analysts can more easily isolate Ecotope-related measures. Discretionary opportunities can occur at any point in the life-cycle of an existing structure.

Categorizing by timing opportunity becomes important when new forecasts of potential savings need to be evaluated. Forecasts are categorized by utility type, vintage, and timing opportunity. The percentage of change between the base case and alternative case is computed for each combination of categories and is used to adjust the estimated base-case ECM count for each ECM within the relevant category. The replaced technology/equipment is computed in the same way.

The results of these computations are made available in ECMMIX, which is a macro- and menu-driven LOTUS 1-2-3 worksheet file. Capabilities of ECMMIX include modifying forecasted savings values, sorting results by any one of four categories, viewing results, and aggregating ECMs or replaced technology across utility regions.

Although the methodology outlined above is straightforward, the data revealed a number of inconsistencies and/or considerations that had to be reconciled. The following sections provide the specifics of these considerations and any necessary assumptions that were adopted. 


\subsection{ECMMIX DEVELOPMENT}

Development of ECMMIX began with a file (BPADATA) containing ECM specific data, including:

- percentage of regional floorspace served by electricity

- building floorspace (1000 sq. ft. per prototypical building)

- savings rate (kWh savings/1000 sq. ft.)

- regional savings potential (aMW).

Each ECM and its savings potential were to fall ultimately into one of the following categoricai combinations:

- ECM Description

- Utility Sector: investor-owned-utility, public utility

- Vintage: existing (pre-1981 building stock), new (post-1991 building stock)

- Building Type: large office, small office, large retail, small retail, school, warehouse, restaurant, grocery, hote]/motel, hospital

- Timing Dpportunity: lost opportunity, discretionary, remodel, renovation

- Measure End-use Category: lighting end uses, other end uses

- Fuel Type Affected: electricity only, electricity or gas.

\subsubsection{Split Composite Measures}

Before the ECM mix could be computed, several adjustments to BPADATA were required. The first adjustment involved ECMs that are a composite of two or more individuals ECMs. It was necessary to separate composite ECMs into their individual components. This was accomplished by prorating the composite ECM regional savings and savings rate, using the ratio of an individual $\mathrm{ECM}^{\prime} \mathrm{s}$ savings potential to the group total provided in the UIC report (1988, Tables 6.1 and 6.2). The composite ECM splits and their ratios are shown below by applicable building type. 
TABLE 2.1.

Building Type/ECM

- Hotel

Efficient incandescents

Efficient lamps (32-watt)

- Hospita]

Efficient incandescents

Parabolic reflectors

- Grocery

Refrig, anti-sweat timer

Beverage case timer

- Large Office (New Buildings)

T-8 Fluorescents

Efficient incandescents

- Large Office (Existing Buildings)

Efficient lamps

Efficient incandescents

- Restaurant

Efficient incandescents

Efficient lamps

Parabolic reflectors

- School

Efficient incandescents

Efficient lamps (32-watt)
Composite

ECM Share

0.81

0.19

0.22

0.78

0.60

0.40

0.84

0.16

0.85

0.15

0.54

0.22

0.24

0.08

0.92

\subsubsection{ADM ECMS}

Energy conservation measures in the ADM study are refrigeration measures that apply to either restaurants or grocery stores; they were added to BPADATA to develop a more comprehensive representation of the refrigeration ECMs that are available in the marketplace. Details of ADM measure stack development can be reviewed in Commercial Refrigeration Resource Assessment (Wikler and Alereza 1988).

Refrigeration measures from ADM exhibit the same problem as the composite ECMs; that is, each measure listed in BPADATA is essentially a combination of measures. Further complicating the issue is that neither the ADM report nor the ECM description directly identifies the actual equipment or technology making up the composite ECM for a particular building type. Instead, each ECM reflects a particular range of the region-wide energy conservation supply curve provided by ADM. The procedures used in determining 
the equipment and/or technology making up a composite measure and the replaced equipment/technologies are fully explained in Appendix A.

\subsubsection{Line Item Adjustments}

Certain adjustments to the savings rate and savings potential of ECMs in BPADATA were necessary to prevent overestimation of the number of ECMs needed to achieve the forecasted potential; they include adjustments for competing fuel-type floorspace and line-loss credits.

The savings rate values provided in BPADATA have an adjustment for electricity fuel-type floorspace built in, but the savings potential values do not. To calculate the number of ECMs needed without adjusting the savings rate would result in an overestimation of ECMs. Thus, where an ECM is sensitive to the fuel type, the savings rate is adjusted by dividing this parameter by the fuel share assigned to the measure (the fuel type shares are resident in BPADATA). This adjustment increases the savings rate value and ultimately decreases the number of measures needed to achieve the forecasted savings potential.

In the original forecasting procedures, the savings potential was given a line-loss credit of 1.075. Again, to prevent overestimation of the number of ECMs, this credit had to be backed out of the savings potential values. To make this adjustment, the savings potential of each ECM was divided by the line-loss credit of 1.075 , which reduces the savings potential and ultimately decreases the number of measures needed to achieve it.

\subsubsection{Measure Consolidation}

In the version of BPADATA provided by BPA, there were ECMs applicable to three composite building types in addition to the ten building types identified in section 2.2. These composite building types included "miscellaneous," "college," and "health." Each composite building type is identified with ECMs lifted from a subset of the other building-type ECMs according to a BPA distribution criteria. The composite building types were created out of a need to represent commercial facilities that were not covered by the UIC studies. 
Only the ten building types identified in section 2.2 are needed for the RP/EIS; thus, it was necessary to collapse each composite building-type ECM into its respective parent building-type ECM. For example, an ECM associated with college buildings may actually originate from the large-office-buildingtype category. The consolidation process involved adding the savings potential of the composite building-type ECM to that of its parent building-type ECM. The savings rate is retained from that reported for the parent buildingtype ECM.

In certain instances, a parent building-type ECM did not exist for a composite building type ECM, due to elimination by the price-induced screening process of the forecasting procedure. In this case, the potential savings was retained from the composite building type ECM, but the savings rate is calculated. The calculation involved determining the ratio of the savings rates for composite to parent building-type ECMs of ECMs within the same category and applying the ratio to the parentless composite building-type ECM savings rate.

An additional consolidation effort was needed, in which ECMs were identified in a vintage category called "recent." This category of buildings corresponded to structures built between 1981 and 1985 and was treated uniquely in the forecasting procedures, to incorporate the consideration of newly adopted building codes and standards during this period. Since some of the ECMs associated with pre-1981 structures are now required by building codes, interactive effects of some ECMs result in reduced potential savings estimates, or the ECM is not included in the 1 ist of discretionary adoptable ECMs if the structure was built during the "recent" period. ECMs associated with "recent" vintages were consolidated with like ECMs in the "existing" vintage category in the same manner as described above for composite building type ECMs.

\subsubsection{Renovation and Remodel Measures}

Additional ECMs were added to the measure stack of BPADATA to more fully represent measures associated with major remodel and/or renovation activities beyond those of existing lost opportunities. These ECMs were provided by BPA from the Ecotope study. Due to extensive uncertainties inherent in the 
Ecotope study, BPA provided a list of the ECM savings potential and required ECMs to achieve that potential directly. That is, no further calculation of the ECM mix was required except in the case of heating, ventilation and air conditioning (HVAC) measures. In the case of HVAC measures, potential savings were provided along with the corresponding required number of buildings.

Extensive professional judgement was exercised in obtaining the end-use applications per building, because that information was not provided by ECOTOPE. The list of HVAC ECMS and assumptions employed in determining their end-use applications is provided in Appendix B.

\subsubsection{Estimation of ECM Mix}

To derive the ECM mix and the technology/equipment replaced, it was first necessary to establish the number of ECMs per prototypical building and the replacement rate per ECM adopted. Appendix $C$ presents the estimates of ECMs per building. Replaced equipment/technology per ECM are available in ECMMIX. A large share of the ECMs do not replace any equipment/technology, because they are retrofit measures that add to a system. Where replacements do occur, ECMs generally replace equipment/technology one-for-one; for other cases a multiplier is built into ECMMIX that calculates the correct number of replacements.

With the ECMs per building established, calculating the number of ECMS and replacements associated with forecasted savings potential is straightforward as described in Section 2.1. That is, the number of buildings associated with the savings potential is computed and multiplied by the ECMs per building type. At this point BPADATA is fully developed for incorporation into ECMMIX. 


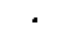




\subsection{ECMMIX USER GUIDE}

The following sections describe the capabilities of ECMMIX. Included are a discussion of the procedures and options available to the user and concluding remarks.

\subsection{USER CAPABILITIES}

ECMMIX pulls together the data of BPADATA, baseline conditions of applicable building types, and data manipulation capabilities and results. The tool is a LOTUS 1-2-3 worksheet file with macro-driven menus that lead a user through an analysis session. User requirements consist of an IBM PC or clone, LOTUS 1-2-3, and a beginner's understanding of LOTUS 1-2-3.

To access ECMMIX.WKl, retrieve the file as any other worksheet file would be loaded. An introductory screen appears and is shown below:

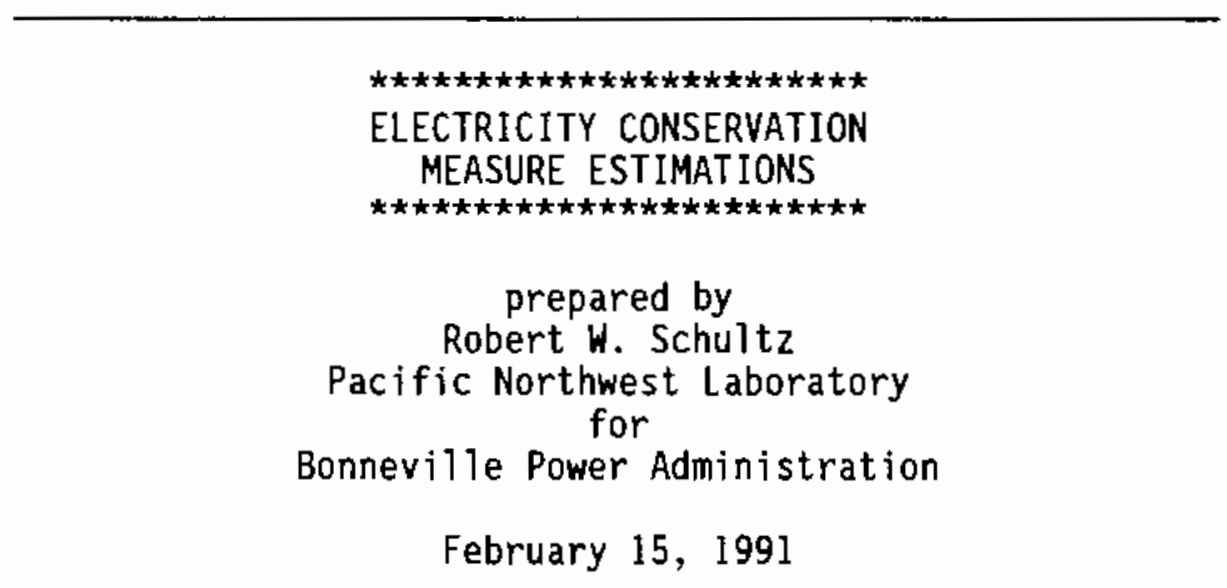

$\gg \gg$ Strike ALT A to initiate the analysis macro $\ll \ll<$

From the introductory screen, and after striking ALT A (strike the keys simultaneously), the macro process will be activated and will guide the user through an analysis session. The next screen presented to the user appears be 7 ow: 
You now have the option to perform one of the menu

items shown at the top of the screen and described below.

\begin{tabular}{|c|c|}
\hline ORE_MW: & $\begin{array}{l}\text { Show and/or change the current forecasted megawatt } \\
\text { savings. }\end{array}$ \\
\hline $\begin{array}{l}\text { IEW: } \\
\text { TILITY_TYPE: }\end{array}$ & $\begin{array}{l}\text { View the ECM measure stack. } \\
\text { Sort the ECMs by utility type (IOU vs Public) } \\
\text { and vintage. }\end{array}$ \\
\hline UILDING_TYPE: & $\begin{array}{l}\text { Sort the ECMs by building type (LO, SO, etc.) } \\
\text { and by Utility type. }\end{array}$ \\
\hline TIMING: & $\begin{array}{l}\text { Sort the ECMs by timing category (Lost Opportunity, } \\
\text { discretionary, remodel, renovation) and utility type. }\end{array}$ \\
\hline$E:$ & $\begin{array}{l}\text { Sort the ECMs by measure description and utility type. } \\
\text { Select to sort on ECMS or replacements. } \\
\text { Select to terminate the analysis. }\end{array}$ \\
\hline
\end{tabular}

Each of the options described in the above screen will appear in the command line of the worksheet, and one should be selected in the same manner as selecting options in other LOTUS 1-2-3 worksheet files. That is, either move the cellpointer to the desired option or simply type the first character of the option.

If the user selects FORE_MW, a new screen will reveal the Megawatt Savings Summary TabTe, and the menu options MODIFY and CONTINUE will appear on the command line. Selecting MODIFY will transfer control to the user and allow changes to be made to the highlighted sections of the summary table. It is through this avenue that a user enters new forecasts for potential savings. That is, alternative projections of savings potential will be in terms of utility type, vintage and/or timing opportunity, and a11 ECMs associated with an altered savings category will be adjusted accordingly. Once all changes have been entered the user strikes ALT B to reactivate the macro process. If no changes are to be made to the summary table, the user can then select option CONTINUE to return to the previous set of menu options. The summary table is shown below in Table 3.1. In this example, a new savings forecast 
TABLE 3.1. Megawatt Savings Summary Table. Alternative Case 1

\begin{tabular}{|c|c|c|c|c|c|}
\hline $\begin{array}{l}\text { Conservation } \\
\text { Acquisition }\end{array}$ & & Averag & atts & $\begin{array}{r}\text { Percen } \\
\text { Base } \\
\end{array}$ & $\begin{array}{l}\text { of } \\
\text { Case }\end{array}$ \\
\hline Alternative & Category & Public & $\underline{10 U}$ & Public & $10 \mathrm{~V}$ \\
\hline $\begin{array}{l}\text { Basecase: } \\
\text { Total Basecase: }\end{array}$ & $\begin{array}{l}\text { Existing-Discr. } \\
\text { Existing-Lost Opp. } \\
\text { New-Lost Opp. }\end{array}$ & $\begin{array}{r}45 \\
85 \\
170 \\
300\end{array}$ & $\begin{array}{r}73 \\
95 \\
389 \\
558\end{array}$ & $\begin{array}{l}-- \\
-- \\
--\end{array}$ & $\begin{array}{l}-- \\
-- \\
--\end{array}$ \\
\hline $\begin{array}{l}\text { Alternative: } \\
\text { Total Alternative: }\end{array}$ & $\begin{array}{l}\text { Existing-Discr. } \\
\text { Existing-Lost Opp. } \\
\text { New-Lost Opp. }\end{array}$ & $\begin{array}{r}90 \\
85 \\
170 \\
\end{array}$ & $\begin{array}{r}73 \\
95 \\
389 \\
345\end{array}$ & $\begin{array}{l}2.00 \\
1.00 \\
1.00\end{array}$ & $\begin{array}{r}1.00 \\
1.00 \\
1.00 \\
558\end{array}$ \\
\hline
\end{tabular}

for existing discretionary-public-utility ECMs has been entered as reflected by the percent of base-case value shown. All ECM estimates associated with this category will be adjusted by a factor of 2.0 .

The options UTILITY_TYPE, BUILDING_TYPE, TIMING, and ECM all relate to sorting capabilities. As described in the options screen, the results of computations specific to the current values of the summary table will be sorted on primary and secondary keys. For example, if the user selected TIMING, all results would be sorted first by timing opportunity (in ascending order; e.g., discretionary, lost opportunity, remoder, and renovation) and second, by utility type.

Once the sorting process has been completed, the options menu reappears on the command line. By selecting VIEW the user can peruse the results and return to the options menu by striking any key. Selecting the AGGREGATE option wi1l present a menu with choices of NEW_TECHNOLOGY and REPLACED_TECHNOLOGY. Selecting the first choice will collapse a11 like ECMs by utility type. Selecting REPLACED_TECHNOLOGY will collapse all like replaced equipment/technology, again by utility type. In either aggregation procedure, certain classifications of ECMs or replaced equipment will be lost. For example, the building type associated with an ECM can no longer be retained when collapsing two like ECMs with different building type origins.

The Tast option of the options menu is the QUIT option. By selecting QUIT the macro process cleans up the worksheet and notifies the user to save 
any desired results under a new file name for future use. Control is then transferred to the user, where further analyses can be implemented at will.

The results section of ECMMIX is 15 columns wide. For presentation purposes it is shown below in a horizontal manner, allowing easy visual representation of ECMMIX results (Table 3.2 ).

To demonstrate the data provided by ECMMIX consider line two of the results shown below. The ECM adopted is efficient incandescent light fixtures applicable to existing large office buildings in investor-owned utility regions. This ECM is a lighting measure affecting the electricity fuel type and is available for adoption at any time during the life cycle of the building (i.e., discretionary timing opportunity). According to BPA base-case forecasts, this ECM could save 0.315 average megawatts regionwide, corresponding to 96,237 fixtures. Since there is a one-to-one replacement rate, 96,237 100-watt incandescent downlight fixtures are replaced. The a]ternative forecasted savings potential is the same as the base-case forecasts; therefore, the ECM estimate is unchanged from that of the base case.

\subsection{CONCLUSIONS}

The ECMMIX tool was developed to provide BPA analysts with the ability to quickly and easily evaluate the impact on the ECM mix associated (and equipment/technology replaced) with a given alternative regional forecast of electricity savings potential. A base-case forecast was provided by BPA to serve as a point of departure for alternative forecasts. More specificaliy, a base-case ECM mix has been estimated from a base-case forecast of regional megawatt savings. In addition, equipment and technology replaced from adoption of the ECM mix has been provided. When alternative forecasts of regional savings are under consideration, ECMMIX is capable of calculating a new set of estimates for the associated ECM mix and the equipment replaced.

The entire results section of ECMMIX is too large to be represented in this document, but it can be reviewed in an analysis session using ECMMIX. Problems or questions regarding the use of the ECMMIX tool can be directed to the author. 
TABLE 3.2. ECMMIX Resuits

\begin{tabular}{|c|c|c|c|c|c|}
\hline $\begin{array}{c}\text { Building } \\
\text { Type }\end{array}$ & $\begin{array}{c}\text { Utility } \\
\text { Type } \\
\text { (IIItou, } \\
\text { P=Public) } \\
\end{array}$ & $\begin{array}{c}\text { vintage } \\
\text { cN=New, } \\
\underline{E=E x i s t .2}\end{array}$ & $\begin{array}{l}\text { Measure } \\
\text { End-use } \\
\text { category } \\
\text { (L=Ltg.. } \\
\text { O=other }\end{array}$ & $\begin{array}{c}\text { Fuel } \\
\text { Iype } \\
\text { Affected } \\
\text { (E=Electric, } \\
\text { G=Gas) } \\
\end{array}$ & $\begin{array}{c}\text { Oiscre., } \\
\text { lost } \\
\text { Opp. } \\
\text { ReNodel, } \\
\text { ReNovation } \\
\end{array}$ \\
\hline $\begin{array}{l}S R \\
L 1 \\
L A \\
L A \\
L R \\
L O\end{array}$ & $\begin{array}{l}I \\
1 \\
1 \\
1 \\
I \\
I \\
I\end{array}$ & $\begin{array}{l}E \\
E \\
E \\
E \\
E \\
E \\
E\end{array}$ & $\begin{array}{l}0 \\
\mathrm{~L} \\
\mathrm{~L} \\
\mathrm{~L} \\
0 \\
0\end{array}$ & $\begin{array}{l}G \\
\text { E } \\
E \\
E \\
G \\
G\end{array}$ & $\begin{array}{l}01 \\
01 \\
01 \\
01 \\
01 \\
01 \\
0 I\end{array}$ \\
\hline $\begin{array}{l}\text { LR } \\
L O \\
G R \\
G R\end{array}$ & $\begin{array}{l}I \\
I \\
I \\
I\end{array}$ & $\begin{array}{l}\varepsilon \\
E \\
E \\
E\end{array}$ & $\begin{array}{l}\mathrm{L} \\
0 \\
0 \\
\mathrm{~L}\end{array}$ & $\begin{array}{l}E \\
G \\
G \\
E\end{array}$ & $\begin{array}{l}D I \\
D I \\
D I \\
D I\end{array}$ \\
\hline
\end{tabular}

\begin{tabular}{|c|c|c|c|c|c|c|}
\hline $\begin{array}{l}\text { Ave. MH } \\
\text { savings in } \\
\text { Base-case } \\
\text { Scenario }\end{array}$ & $\begin{array}{l}\text { Total Number } \\
\text { of ECMs in } \\
\text { Base-case } \\
\text { Scenario } \\
\end{array}$ & $\begin{array}{l}\text { Ave. MH } \\
\text { Savings in } \\
\text { Al ternative } \\
\text { Scenario } \\
\end{array}$ & $\begin{array}{l}\text { Total Number } \\
\text { of ECMs in } \\
\text { Al ternative } \\
\text { Scenario } \\
\end{array}$ & $\begin{array}{l}\text { Basel ine } \\
\text { scenara io } \\
\text { Equipment } \\
\text { ouantity } \\
\text { Replaced }\end{array}$ & $\begin{array}{l}\text { Al ternative } \\
\text { scenari io } \\
\text { Equipnent } \\
\text { Quarti ity } \\
\text { Replaced }\end{array}$ & $\begin{array}{l}\text { Type of } \\
\text { Equipnent } \\
\text { Replaced }\end{array}$ \\
\hline $\begin{array}{l}0.357 \\
0.315 \\
0.214 \\
1.787 \\
0.114 \\
1.832\end{array}$ & $\begin{array}{r}2,815 \\
96,237 \\
9,409 \\
2,004,930 \\
897 \\
141\end{array}$ & $\begin{array}{l}0.357 \\
0.315 \\
0.214 \\
1.787 \\
0.114 \\
1.832\end{array}$ & $\begin{array}{r}2,815 \\
96,237 \\
9,409 \\
2,004,930 \\
897 \\
141\end{array}$ & $\begin{array}{r}96,20 \\
9,237 \\
9,409 \\
2,004,930 \\
0 \\
0\end{array}$ & $\begin{array}{r}96,237 \\
9,409 \\
2,004,930 \\
0 \\
0\end{array}$ & $\begin{array}{l}\text { NA } \\
100 \text {-watt incandescent downlight fixtures } \\
150 \text {-watt floodl i ights } \\
40 \text {-watt fluorescent lamps } \\
\text { NA } \\
\text { NA }\end{array}$ \\
\hline $\begin{array}{r}0.087 \\
16.003 \\
1.726 \\
0.628\end{array}$ & $\begin{array}{r}14,238 \\
28,189,060 \\
704 \\
27,037\end{array}$ & $\begin{array}{r}0.087 \\
16.003 \\
1.726 \\
0.628\end{array}$ & $\begin{array}{r}14,238 \\
28,189,060 \\
704 \\
27,037\end{array}$ & $\begin{array}{r}14,238 \\
0 \\
0 \\
27,037\end{array}$ & $\begin{array}{r}14,238 \\
0 \\
0 \\
27,037\end{array}$ & $\begin{array}{l}\text { TS0-watt floodtights } \\
\text { NA } \\
\text { NA } \\
150 \text { - watt floodtights }\end{array}$ \\
\hline
\end{tabular}





\subsection{REFERENCES}

Bonneville Power Administration (BPA). January 1990. Draft 1990 Conservation Resources Supply Document. Bonneville Power Administration, Portland, Oregon.

Bonneville Power Administration (BPA). January 1990. Draft 1990 Conservation Resources Supply Document Technical Documentation. Bonneville Power Administration, Portland, Oregon.

Katz, G., D. Baylon, and F. Gordon. 1989. Lost Conservation Opportunities Created by Remodeling and Renovation in the Commercial Sector. Momentum Engineering and Ecotope, Seatt]e, Washington.

United Industries Corporation (UIC). Juiy 1987. DOE-2 Commercial Building Prototype Review and Revision, Warehouse. United Industries Corp., Bellevue, Washington.

United Industries Corporation (UIC). August 1987. DOE-2 Commercial Building Prototype Review and Revision, Small office. United Industries Corp., Bellevue, Washington.

United Industries Corporation (UIC). December 1987. DOE-2 Commercial Building Prototype Review and Revision, Large office. United Industries Corp., Bellevue, Washington.

United Industries Corporation (UIC). February 19B8. DDE-2 Commercial Building Prototype Review and Revision, Hospital. United Industries Corp., Bellevue, Washington.

United Industries Corporation (UIC). March 1988. DOE-2 Commercial Building Prototype Review and Revision. Fast Food Restaurant. United Industries Corp., Bellevue, Washington.

United Industries Corporation (UIC). March 1988. DOE-2 Commercial Building Prototype Review and Revision. Hotel. United Industries Corp., Bellevue, Washington.

United Industries Corporation (UIC). March 1988. DOE-2 Commercial Building Prototype Review and Revision, Large Retail. United Industries Corp., BelTevue, Washington.

United Industries Corporation (UIC). March 1988. DOE-2 Commercial Building Prototype Review and Revision, Small Retail. United Industries Corp., Bellevue, Washington.

United Industries Corporation (UIC). June 1988. DOE-2 Commercial BuiTding Prototype Review and Revision, Grocery. United Industries Corp., Bellevue, Washington. 
United Industries Corporation (UIC). June 1988. DOE-2 Commercial Building Prototype Review and Revision, School. United Industries Corp., BelTevue, Washington.

Wikler, G. A., and T. Alereza. 1988. Commercial Refrigeration Resource Assessment. ADM Associates Inc., Sacramento, California. 
APPENDIX A

AOM REFRIGERATION ECMS 
APPENDIX A

\section{ADM REFRIGERATION ECMS}

Presented below are the procedures adopted for splitting ADM refrigeration measures into individual ECMs in BPADATA. ADM data development will not be repeated here, but can be reviewed in Commercial Refrigeration Resource Assessment (Wikler and Alereza 1988).

The ADM study did not provide a sufficient data disaggregation to determine ECM shares of the savings potential. Individual ECMS are identified only when linked with the regional savings as a whole. To determine the amount to which an individual ECM contributes to the region total, and more importantiy, assign it to a building and vintage category, it was first necessary to determine whether a building/vintage category could physically adopt the ECM. Also, any ECMs already represented by the UIC studies are excluded.

Next, the share the remaining ECMs contribute to the regional savings potential within a given building/vintage is used to distribute the savings potential and savings rates shown in BPADATA.

The ADM study did identify the number of system applications a particular ECM could affect. These were extracted and used to reflect the number of units per building type in BPADATA. An assumption was adopted that presumes $100 \%$ application rate in all applicable end-uses of a building.

Once all composite ADM measures were split into individual ECMs in BPADATA, a comparison of the number-of-buildings calculation (across like line-item measures) revealed identical estimates. It could only be assumed that each ECM savings rate used in calculating the savings potential had an adjustment for applicable floorspace availability built in, meaning that the calculated number of buildings for any particular line item represents the total number of buildings needed to achieve the sum of each like line-item savings potential. 
ADM equipment/technology replacements for each ECM are available in ECMMIX. In a17 ADM refrigeration measures where replacements occur, substitutions are one-for-one with ECMs adopted.

The disaggregation process described above resulted in the following 7ist of individual ECMs for each composite ADM measure. The ECMs are grouped by vintage and building type and by ADM composite ECM (e.g., ADM.E.GR.RI refers to existing grocery stores, range 1 of the energy conservation supply curve). Included is the number of units per building type affected by ECM adoption and the share of the BPADATA savings rate and savings potential attributable to the individual $\mathrm{ECM}$.

TABLE A.1. ADM Composite ECM Distributions and Unit Estimates

\begin{tabular}{cc}
$\begin{array}{c}\text { Units } \\
\text { per }\end{array}$ & $\begin{array}{c}\text { Composite } \\
\text { ECM } \\
\text { Building }\end{array}$ \\
\hline
\end{tabular}

\section{Existing Grocery}

ADM.E.GR.R1

Floating condenser head press. cntrl. 14 Liquid pressure amplifier 14 Hot gas defrost Ambient sub-coolers

Shell improvements

ADM.E.GR.R2

Screw compressor

Parallel unequal compressor

14

Floating condenser head press. cntrl. Liquid pressure amplifier

High efficiency fan

Ambient sub-coolers

Sheil improvements

ADM.E.GR.R3

Screw compressor

0.13

Paral7el unequat compressor

Floating condenser head press. cntrl.

$\begin{array}{rr}14 & 0.25 \\ 14 & 0.04 \\ 14 & 0.05 \\ 14 & 0.26 \\ 16 & 0.03 \\ 14 & 0.06 \\ 2 & 0.31\end{array}$


TABLE A.1. (contd)

Building Type

\begin{tabular}{cc} 
Units & Composite \\
per & ECM \\
Building & Share \\
\hline
\end{tabular}

Existing Grocery (contd)

ADM.E.GR.R4

Screw compressor

Parallel unequal compressor

14

0.44

Floating condenser head press. cntrl.

14

0.05

Liquid pressure amplifier

14

14

Evaporative pre-cooler

14

High-efficiency fan

16

Ambient sub-coolers

She11 improvements

Heat recovery

0.01

0.11

0.01

0.02

0.01

$0.0 \mathrm{~B}$

2

14

0.27

ADM.E.GR.R5

Paralle] unequal compressor

14

14

0.63

Evaporative pre-cooler

High-efficiency fan

Mechanical sub-cooler

ADM.E.GR.R6

Screw compressor

Parallel unequal compressor

Floating condenser head press. cntrl.

Variable speed compressor

14

0.07

High-efficiency fan

Ambient sub-coolers

Shell improvements

14

0.01

14

0.06

14

0.03

2

0.09

ADM.E.GR.R7

Variable speed compressor

14

16

0.88

0.12

New Grocery

ADM.N.GR.RI

Floating condenser head press. entrl.

12

0.36

Liquid pressure amplifier

Hot gas defrost

Ambient sub-coolers

Shelt improvements

ADM.N.GR.R2

Screw compressor

Parallel unequal compressor

Floating condenser head press. cntrl. 
IABLE A.1. (contd)

Building Type

Liquid pressure amplifier

High efficiency fan

Ambient sub-coolers

Shell improvements

ADM.N.GR.R3

Screw compressor

Parallel unequal compressor

Floating condenser head press. cntrl.

Liquid pressure amplifier

High-efficiency fan

Ambient sub-coolers

Shell improvements

ADM.N.GR.R4

Screw compressor

Parallel unequal compressor

Floating condenser head press. cntrt.

Liquid pressure amplifier

Evaporative pre-cooler

High-efficiency fan

Ambient sub-coolers

Shell improvements

Heat recovery

ADM.N.GR.R5

Parallel unequal compressor

Evaporative pre-cooler

High-efficiency fan

Mechanical sub-cooler

ADM.N.GR.RE

Screw compressor

Parallel unequal compressor

Floating condenser head press. cntrl.

Variable speed compressor

High-efficiency fan

Ambient sub-coolers

Shell improvements

ADM.N.GR.R7

Variable speed compressor

High-efficiency fan

\begin{tabular}{cc}
$\begin{array}{c}\text { Units } \\
\text { per }\end{array}$ & $\begin{array}{c}\text { Composite } \\
\text { ECM }\end{array}$ \\
Building & Share \\
\hline
\end{tabular}

12

0.27

$14 \quad 0.02$

$12 \quad 0.05$

20.13

$12 \quad 0.25$

$12 \quad 0.04$

$12 \quad 0.05$

$12 \quad 0.26$

$14 \quad 0.03$

$12 \quad 0.06$

$2 \quad 0.31$

$12 \quad 0.44$

$12 \quad 0.05$

$12 \quad 0.01$

120.11

$12 \quad 0.01$

$14 \quad 0.02$

$12 \quad 0.01$

20.08

$12 \quad 0.27$

$12 \quad 0.63$

$12 \quad 0.04$

$14 \quad 0.14$

$12 \quad 0.20$

$12 \quad 0.48$

$12 \quad 0.25$

$12 \quad 0.07$

$12 \quad 0.01$

$14 \quad 0.06$

$12 \quad 0.03$

$2 \quad 0.09$

12

0.88

$14 \quad 0.12$ 
IABLE A.1. (contd)

Building Type

\begin{tabular}{cc} 
Units & Composite \\
per & ECM \\
Building & Share \\
\hline
\end{tabular}

Existing Restaurant

ADM.E.RE.R2

Floating condenser head press, cntrl. Liquid pressure amplifier

High-efficiency fan

Ambient sub-coolers

Shel1 improvements

3

0.31

3

0.39

$\begin{array}{ll}7 & 0.03\end{array}$

$3 \quad 0.07$

$4 \quad 0.19$

ADM.E.RE.R3

Floating condenser head press. cntr].

Liquid pressure amplifier

High-efficiency fan

Ambient sub-coolers

Shell improvements

3

0.37

0.04

$\begin{array}{ll}3 & 0.08 \\ 4 & 0.44\end{array}$

ADM.E.RE. R4

Floating condenser head press. cntrl.

0.05

Liquid pressure amplifier

0.47

Evaporative pre-cooler

0.02

High-efficiency fan

Ambient sub-coolers

Shell improvements

0.09

0.02

$4 \quad 0.34$

ADM.E.RE.RG

Floating condenser head press. cntrl. High-efficiency fan

Ambient sub-coolers

Shell improvements

\section{New Restaurant}

ADM.N.RE.R2

Floating condenser head press. cntrl.

Liquid pressure amplifier

High-efficiency fan

0.03

Ambient sub-coolers

She?t improvements

0.07

3

0.19

ADM.N.RE.R3

Floating condenser head press. cntrl. Liquid pressure amplifier 
IABLE A.1. (contd)

Building Type

\begin{tabular}{cc} 
Units & Composite \\
per & ECM \\
Building & Share \\
\hline
\end{tabular}

ADM.N.RE.R4

Floating condenser head press. cntrl.

Liquid pressure amplifier

Evaporative pre-cooler

High-efficiency fan

Ambient sub-coolers

Shell improvements

$3 \quad 0.05$

$3 \quad 0.47$

$3 \quad 0.02$

$\begin{array}{ll}7 & 0.09\end{array}$

$3 \quad 0.02$

$4 \quad 0.34$

ADM.N.RE. R5

Evaporative pre-cooler

High-efficiency fan

$3 \quad 0.21$

$\begin{array}{ll}7 & 0.79\end{array}$

ADM.N.RE. R6

Floating condenser head press. cntrl. High-efficiency fan

Ambient sub-coolers

Shell improvements

$\begin{array}{ll}3 & 0.30 \\ 7 & 0.24 \\ 3 & 0.11 \\ 4 & 0.35\end{array}$

\section{REFERENCE}

Wikler, G. A., and T. Alereza. November 19B8. Commercial Refrigeration Resource Assessment. ADM Associates, Inc., Sacramento, California. 
APPENDIX B

ECOTOPE REMODEL AND RENOVATION ECMS 


\section{APPENDIX B}

\section{ECOTOPE REMODEL AND RENOVATION ECMS}

The following section describes the approach uses to determine the end use applications per building for Ecotope HVAC ECMs. Initialiy, an ECM and system application were compared with the systems identified in the UIC and/or ADM studies. If the systems appeared compatible, the end-use applications were lifted from these sources. If a system was not compatible, or was not present in any configuration for a particular building type, then an ECM's size per square foot was determined for a building type most closely configured to the building type under consideration. Using the square foot sizing and the square footage of the building type under consideration, an estimate of the end-use application could be determined. For example, if the fan horsepower sizing for an ECM is not available for a small office building, then the sizing for horsepower requirements per square foot in large office buildings was determined and multiplied by the small office building square footage. These assumptions and the calculation results are presented in the following tables. 
IABLE B.1. Ecotope HVAC Renovation ECM/Building Assumptions

Building

Type

LO

LO

LO

LO

L.O

LR

LR

LR

$S R$

$S R$

$S R$

$5 R$

RE

RE

GR

GR

$H M$

HM

HM

HM

HM
ECM Description

Chiller water reset

High-eff. motor

High-eff. chiller

Variable speed drive fan

Screw compressor

Energy management system

High-eff. heat pump

Var. spd. drive: circ. pumps

Optimal start timer

High-eff. heat pump

Heat pump

Eff. fan motor

Optimal start timer

Eff. fan motor

Eff. fan motor

High-eff. cooling

High-eff. chiller

Var. spd. drive on circ. pumps

Energy management system

Heat pump

Eff. fan motor
Source of ECM/Building

UIC

UIC

UIC

Assumed equal to high

efficiency motor

Assumed 2-reciprocating

compressors used in 2 chillers

Assumed one system per

building

Assumed ton per sq.ft. equals

that for small retail

$\left(7.5 / 4.8 \mathrm{~B}^{\star} 120\right)$

Assumes one 25-Hp pump per

chiller (2 chillers)

Ecotope assumes one timeclock

for alt units

UIC

UIC

Assumed Hp per sq.ft. equals

that for Large office

$\left(900 / 40 B^{\star 4} 4.88\right)$

Ecotope assumes one timeclock

for all units

Assumed Hp per sq.ft. equals

that for Large office

$(900 / 408 * 2.624)$

Assumed fan motors are used in

each refrigeration case (UIC)

UIC

2-200 ton chillers are present

Assumes one 25-Hp pump per

chiller (2 chillers)

Assumes one system per building

Assumes tons per sq. ft. equals that for high-efficiency heat pump of Smail Retail

$(7.5 / 4.88 * 277)$

Assumed $\mathrm{Hp}$ per sq.ft. equals

that for Large office

$(900 / 408 * 277)$ 
IABLE B.I. (contd)

\begin{tabular}{|c|c|c|}
\hline $\begin{array}{l}\text { Building } \\
\text { Type }\end{array}$ & ECM Description & Source of ECM/Building \\
\hline SC & High-eff. heat pump & $\begin{array}{l}\text { Assumes tons per sq.ft, equals } \\
\text { that for high-efficiency heat } \\
\text { pump of Smail Retail } \\
(7.5 / 4.88 \star 67)\end{array}$ \\
\hline SC & Energy management system & $\begin{array}{l}\text { Assumes one system per } \\
\text { bujlding }\end{array}$ \\
\hline SC & Eff. fan motor & $\begin{array}{l}\text { Assumed Hp per sq.ft. equals } \\
\text { that for Large Dffice } \\
(900 / 408 * 67)\end{array}$ \\
\hline HO & Screw compressor & $\begin{array}{l}\text { Assume } 2 \text { reciprocating } \\
\text { comoressors used in } 2 \text { chillers }\end{array}$ \\
\hline $\begin{array}{l}\mathrm{HO} \\
\mathrm{HO} \\
\mathrm{HO}\end{array}$ & $\begin{array}{l}\text { High-eff. chiller } \\
\text { Chiller water reset } \\
\text { Eff. fan motor }\end{array}$ & $\begin{array}{l}\text { UIC } \\
\text { UIC } \\
\text { Assumed Hp per sq.ft. is same } \\
\text { as that for Large Office } \\
(900 / 408 * 277)\end{array}$ \\
\hline $\begin{array}{l}L O=L a r \\
R E=\operatorname{Re} \\
H O=H O\end{array}$ & $\begin{array}{l}\text { fice, } L R=\text { Large Retaj } \\
\text { Int, } G R=\text { Grocery, } H M=\end{array}$ & $\begin{array}{l}\text { Sinall Retail, } \\
\text { lote1, SC = School, }\end{array}$ \\
\hline
\end{tabular}


TABLE B.2. Ecotope HVAC Renovation ECMS

\begin{tabular}{|c|c|c|c|}
\hline $\begin{array}{l}\text { Building } \\
\text { Type }\end{array}$ & ECH Description & $\begin{array}{c}\text { Number of } \\
\text { Units/ } \\
\text { Building }\end{array}$ & Units \\
\hline LO & Chiller water reset & 2 & Chillers \\
\hline LO & High-eff. motor & 900 & $\mathrm{Hp}$ \\
\hline LO & High-eff. chiller & 2 & Chillers \\
\hline LO & Variable speed drive fan & 900 & $H p$ \\
\hline LO & Screw compressor & 2 & Compressors \\
\hline LR & Energy mangmt. system & j & System \\
\hline LR & High-eff. heat pump & 184 & Ton \\
\hline LR & Var. spd. drive on circ. pumps & 50 & $\mathrm{Hp}$ \\
\hline SR & Optimal start timer & 1 & Timer \\
\hline SR & High-eff. heat pump & 7.5 & Ton \\
\hline SR & Heat pump & 27.5 & Ton \\
\hline SR & Eff. fan motor & 11 & Hp \\
\hline RE & Optimal start timer & 1 & Timer \\
\hline RE & Eff. fan motor & 6 & $\mathrm{Hp}$ \\
\hline GR & Eff. fan motor & 14 & Units \\
\hline GR & High-eff. cooting & 14 & Refrig. cases \\
\hline HM & High-eff. chiller & 2 & Chillers \\
\hline HH & Var. spd. drive on circ. pumps & 50 & Hр \\
\hline HM & Energy mangmt. system & 1 & System \\
\hline HH & Heat pump & 425 & Tons \\
\hline$H M$ & Eff. fan motor & 611 & $\mathrm{Hp}$ \\
\hline SC & High-eff. heat pump & 103 & Ton \\
\hline SC & Energy mangmt. system & 1 & System \\
\hline SC & Eff. fan motor & 148 & $H p$ \\
\hline HO & Screw compressor & 2 & Compressors \\
\hline HO & High-eff, chiller & 2 & Chillers \\
\hline HO & Chiller water reset & 2 & Chillers \\
\hline HO & Eff. fan motor & 611 & $H_{p}$ \\
\hline
\end{tabular}


IABLE B.3. Ecotope HVAC Renovation Savings Potential and ECM Mix (values are applicable to both investor-owned and public utilities).

\begin{tabular}{|c|c|c|c|c|}
\hline $\begin{array}{l}\text { Building } \\
\text { Type } \\
\end{array}$ & ECM Description & $\begin{array}{l}\text { Ave. MW } \\
\text { Savings }\end{array}$ & $\begin{array}{l}\text { Number of } \\
\text { of B]dgs. }\end{array}$ & $\begin{array}{l}\text { Number of } \\
\text { of ECMs }\end{array}$ \\
\hline LO & Chiller water reset & 0.010 & 2.2 & 4 \\
\hline LO & High-eff. motor & 0.016 & 3.8 & 3429 \\
\hline LO & High-eff, chiller & 0.047 & 1.8 & 4 \\
\hline Lo & Variable speed drive fan & 0.039 & 1.0 & 864 \\
\hline 10 & Screw compressor & 0.058 & 1.9 & 4 \\
\hline LR & Energy mangmt. system & 0.199 & 22.5 & 23 \\
\hline$L R$ & High-eff. heat pump & 0.005 & 0.5 & 26 \\
\hline LR & var. spd. drive on circ. pumps & 0.051 & 14.9 & 3941 \\
\hline$S R$ & Optimal start timer & 0.036 & 118.2 & 354 \\
\hline$S R$ & High-eff. heat pump & 0.050 & 66.5 & 1828 \\
\hline SR & Heat pump & 0.055 & 29.6 & 813 \\
\hline SR & Eff. fan motor & 0.014 & 248.8 & 2737 \\
\hline RE & Optimal start timer & 0.114 & 467.9 & 468 \\
\hline RE & Eff. fan motor & 0.091 & 1387.9 & 8327 \\
\hline GR & Eff. fan motor & 0.026 & 43.3 & 606 \\
\hline GR & High-eff. cooling & 0.060 & 39.2 & 549 \\
\hline$H M$ & High-eff. chiller & 0.004 & 0.4 & 1 \\
\hline HM & var. spd. drive on circ. pumps & 0.005 & 0.6 & $\hat{1}$ \\
\hline$H M$ & Energy mangmt. system & 0.005 & 0.2 & 0 \\
\hline HM & Heat pump & 0.032 & 0.2 & 12 \\
\hline$H M$ & Eff. fan motor & 0.005 & 1.3 & 798 \\
\hline SC & High-eff. heat pump & 0.277 & 29.6 & $B 30$ \\
\hline SC & Energy mangmt. system & 0.125 & 16.4 & 16 \\
\hline SC & Eff. fan motor & 0.043 & 69.7 & 10448 \\
\hline HO & Screw compressor & 0.069 & 2.1 & 4 \\
\hline HO & High-eff. chiller & 0.101 & 4.2 & 8 \\
\hline HO & Chiller water reset & 0.038 & 6.4 & 13 \\
\hline HO & Eff. fan motor & 0.097 & 5.3 & 3176 \\
\hline
\end{tabular}

\section{REFERENCE}

Katz, G., D. Baylon, and F. Gordon. 1989. Lost Conservation Opportunities Created by Remodeling and Renovation in the Commercial Sector. Momentum Engineering and Ecotope, Seatt]e, Washington. 
. 
APPENDIX $C$

ECMS PER PROTOTYPICAL BUILDING 


\section{ECMS PER PROTOTYPICAL BUILDING}

\section{ECMs per Prototypical Building}

Tables C.I and C.2 provide a summary of the ECMs per prototypical building for ECMs associated with existing and new buildings, respectively. The units per building shown below were obtained from the UIC studies (UIC $1987,1988)$.

IABLE C.1. ECMS per Prototypical Building: Existing Buildings.

\begin{tabular}{|c|c|c|c|}
\hline $\begin{array}{l}\text { Building } \\
\text { Type }\end{array}$ & ECM Description & Units & $\begin{array}{c}\text { Units/ } \\
\text { Buildine }\end{array}$ \\
\hline GR & Beverage case timer & Timer & 2 \\
\hline GR & Caulking and weatherstripping & Linear foot & 62 \\
\hline LR & Caulking and weatherstripping & Linear foot & $\mathrm{BO}$ \\
\hline SC & Caulking and weatherstripping & Linear foot & 6274 \\
\hline$S R$ & Caulking and weatherstripping & Linear foot & 40 \\
\hline WA & Caulking and weatherstripping & Linear foot & 168 \\
\hline GR & Contrast controls & Control switch & 58 \\
\hline$G R$ & Destratifjers & Fan & 3 \\
\hline WA & Destratifiers & Fan & 6 \\
\hline $\mathrm{RE}$ & Economizer & Unit & 4 \\
\hline SO & Economizer & Unit & 2 \\
\hline WA & Economizer & Unit & 1 \\
\hline WA & Eff. ballasts (electronic office) & Ballast & 48 \\
\hline GR & Eff. ballasts (electronic sales) & Ballast & 230 \\
\hline GR & Eff. ballasts (electronic storage) & Ballast & 18 \\
\hline$H M$ & Efficient ballasts (electronic) & Ballast & 988 \\
\hline HO & Efficient ballasts (electronic) & Ballast & 4815 \\
\hline LO & Efficient ballasts (electronic) & Ballast & 8500 \\
\hline RE & Efficient ballasts (electronic) & Ballast & 43 \\
\hline SC & Efficient ballasts (electronic) & Ballast & 1378 \\
\hline SO & Efficient ballasts (electronic) & Ballast & 86 \\
\hline WA & Eff ballasts (magnetic warehouse) & Ballast & 32 \\
\hline LR & Efficient baliasts (sales) & Ballast & 2496 \\
\hline SR & Efficient ballasts (sales) & Ballast & 180 \\
\hline LR & Efficjent ballasts (storage) & Ballast & 281 \\
\hline SR & Efficient ballasts (storage) & Ballast & 30 \\
\hline$H M$ & Efficient exhaust hoods & Unit & 4 \\
\hline
\end{tabular}


IABLE C.1. (contd)




IABLE C.1. (contd)

Bujlding

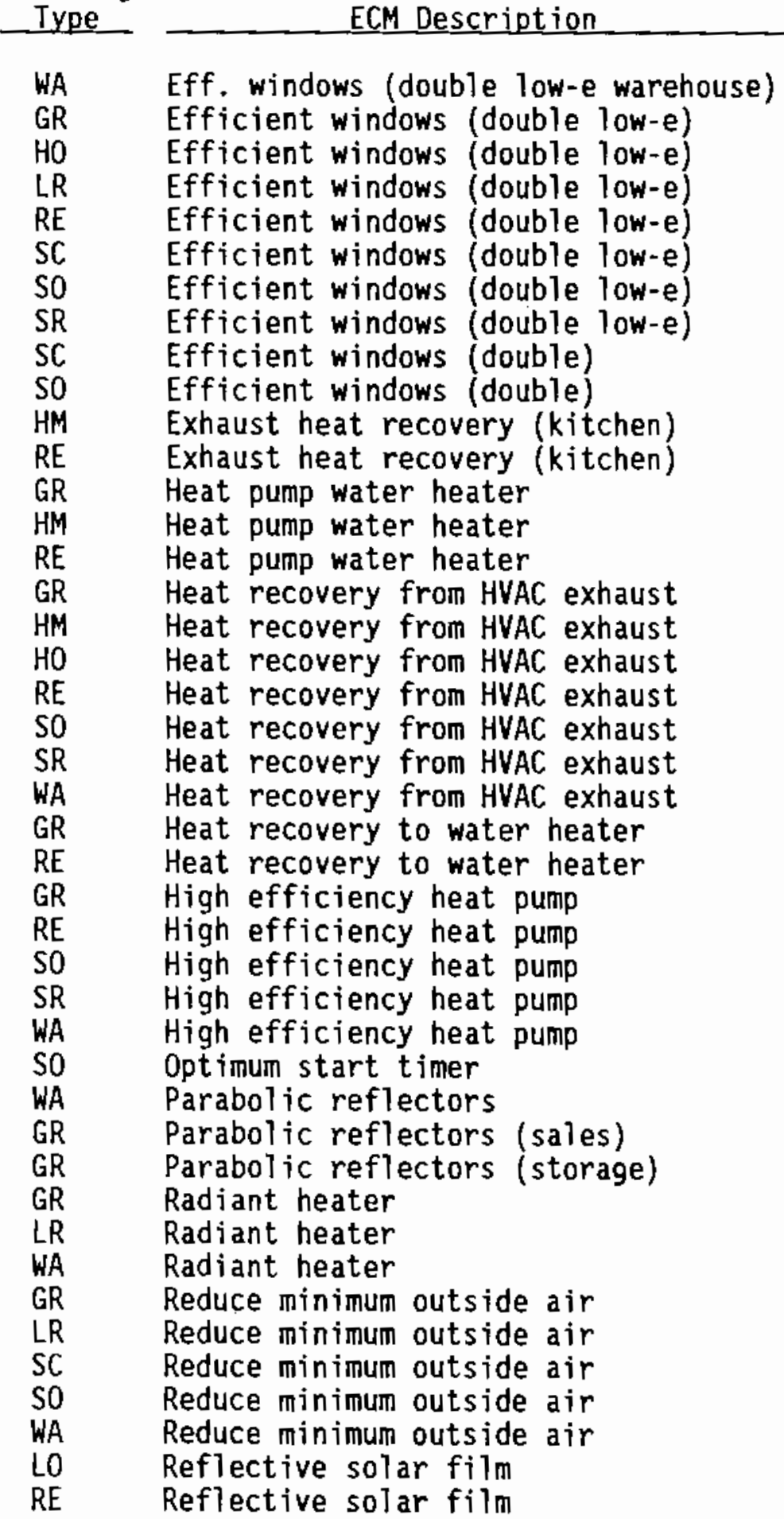

\begin{tabular}{|c|c|}
\hline Units & Buildi \\
\hline Square foot & 410 \\
\hline Square foot & 1080 \\
\hline Square foot & 13613 \\
\hline Square foot & 1530 \\
\hline Square foot & 461 \\
\hline Square foot & 9194 \\
\hline Square foot & 461 \\
\hline Square foot & 490 \\
\hline Square foot & 9194 \\
\hline Square foot & 461 \\
\hline Unit & \\
\hline Unit & \\
\hline Unit & \\
\hline Unit & \\
\hline Unit & \\
\hline Unit & \\
\hline Unit & \\
\hline Unit & \\
\hline Unit & \\
\hline Unit & \\
\hline Unit & \\
\hline Unit & \\
\hline Unit & \\
\hline Unit & \\
\hline Ton & 5 \\
\hline Ton & 16 \\
\hline Ton & I \\
\hline Ton & 27. \\
\hline Ton & \\
\hline Timer & \\
\hline Fixture & \\
\hline Fixture & 230 \\
\hline Fixture & 18 \\
\hline $\mathrm{kW}$ & 40 \\
\hline $\mathrm{kW}$ & 25 \\
\hline $\mathrm{kWH}$ & 13 \\
\hline Labor unit & \\
\hline Labor unit & \\
\hline Labor unit & \\
\hline Labor unit & \\
\hline Labor unit & \\
\hline Square foot & 16167 \\
\hline Square foot & 461 \\
\hline
\end{tabular}


IABLE C.1. (contd)




IABLE C.1. (contd)

Building

Type

ECM Description

Units

Units/

$\begin{array}{ll}\text { LR } & \text { Wall insulation } \\ \text { RE } & \text { Wall insulation } \\ \text { SC } & \text { Wall insulation } \\ \text { SO } & \text { Wall insulation } \\ \text { SR } & \text { Wall insulation } \\ \text { WA } & \text { Wall insulation (office) } \\ \text { WA } & \text { Wall insulation (warehouse) } \\ \text { GR } & \text { Water heater tank insulation } \\ \text { HM } & \text { Water heater tank insulation } \\ \text { LR } & \text { Water heater tank insulation } \\ \text { RE } & \text { Water heater tank insulation } \\ \text { SC } & \text { Water heater tank insulation } \\ \text { SO } & \text { Water heater tank insulation } \\ \text { SR } & \text { Water heater tank insulation } \\ \text { WA } & \text { Water heater tank insulation } \\ \text { GR } & \text { Water heater time clock } \\ \text { LR } & \text { Water heater time clock } \\ \text { RE } & \text { Water heater time clock } \\ \text { SC } & \text { Water heater time clock } \\ \text { SO } & \text { Water heater time clock } \\ \text { SR } & \text { Water heater time clock } \\ \text { WA } & \text { Water heater time clock }\end{array}$

Square foot 25039

Square foot

2191

Square foot

27124

Square foot

3825

Square foot

4218

Square foot

1547

Square foot

8859

Blanket

Blanket

\section{3}

B7anket 4

Blanket I

Blanket 3

Blanket

Blanket

Blanket

Clock unit

Clock unit

Clock unit

Clock unit

clock unit

Clock unit

clock unit

$L O=$ Large Office, $S 0=$ Sma7l Office, $L R=$ Large Retai1,

$S R=$ Smal1 Retail, $R E=$ Restaurant, $G R=$ Grocery, $H M=$ Hotel $/$ Motel, $S C=$ School, $W A=$ Warehouse, $H O=$ Hospital. 
IABLE C.2. ECMs per Prototypical Building: New Buildings.

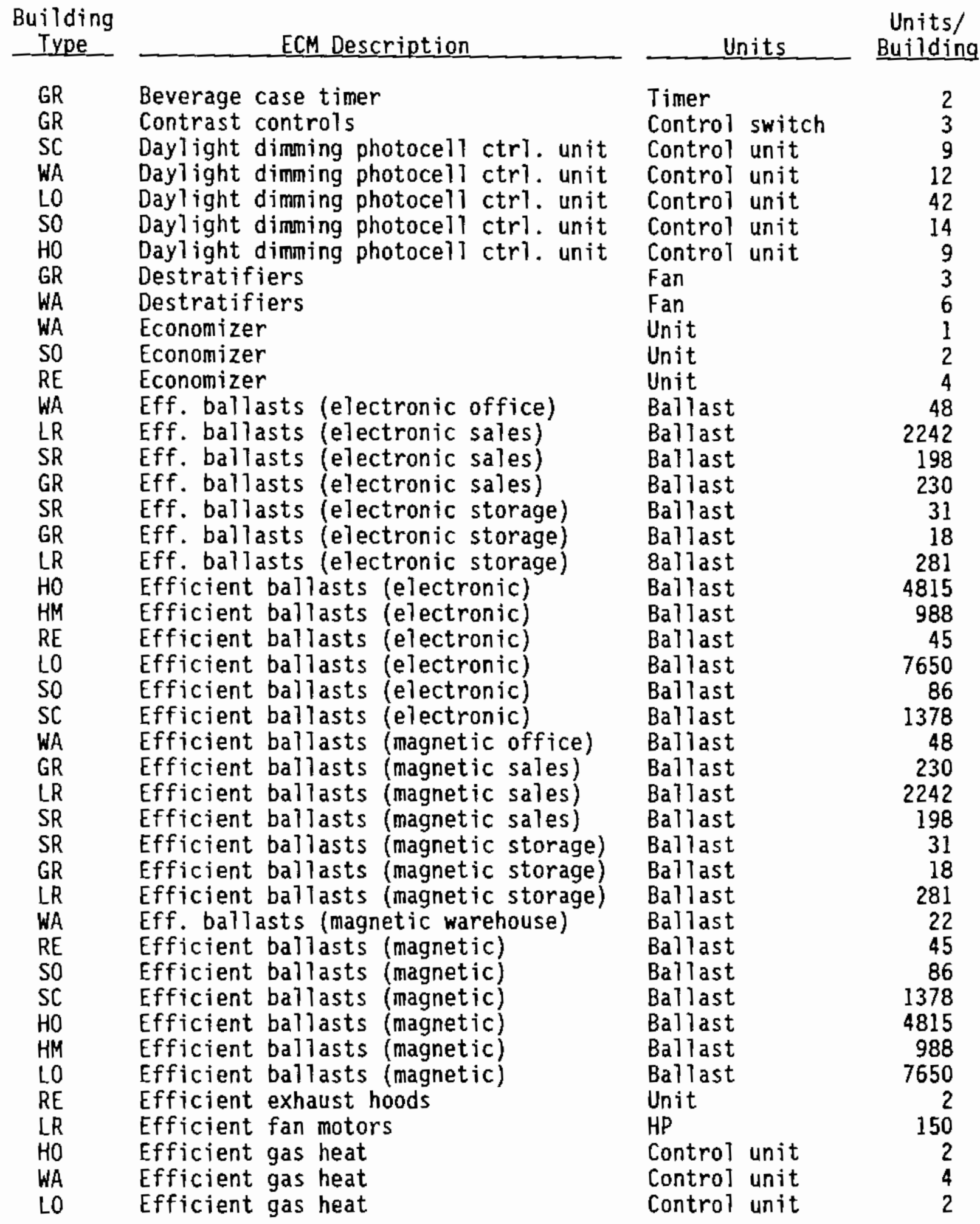


TABLE C.2. (contd)

\begin{tabular}{|c|c|c|c|}
\hline $\begin{array}{l}\text { Building } \\
\text { Type } \\
\end{array}$ & ECM Description & Units & $\begin{array}{c}\text { Units/ } \\
\text { Building }\end{array}$ \\
\hline 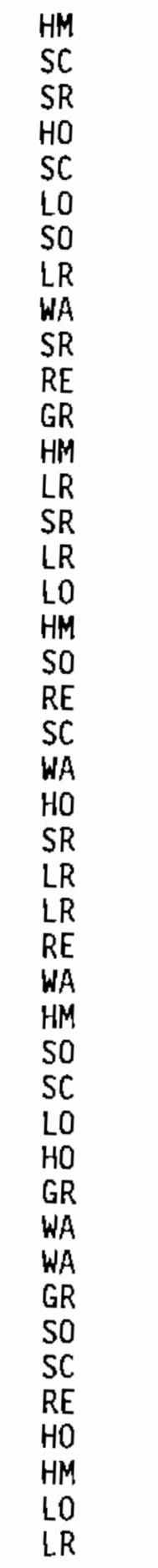 & $\begin{array}{l}\text { Efficient gas heat } \\
\text { Efficient gas heat } \\
\text { Efficient gas heat } \\
\text { Efficient incandescents } \\
\text { Efficient incandescents } \\
\text { Efficient incandescents } \\
\text { Efficient incandescents } \\
\text { Efficient incandescents } \\
\text { Efficient incandescents } \\
\text { Efficient incandescents } \\
\text { Efficient incandescents } \\
\text { Efficient incandescents } \\
\text { Efficient incandescents } \\
\text { Efficient lamps ( } 32 \text {-watt sales) } \\
\text { Efficient lamps ( } 32 \text {-watt sales) } \\
\text { Efficient lamps ( } 32 \text {-watt storage) } \\
\text { Efficient lamps ( } 32 \text {-watt) } \\
\text { Efficient lamps ( } 32 \text {-watt) } \\
\text { Efficient lamps ( } 32 \text {-watt) } \\
\text { Efficient lamps ( } 32 \text {-watt) } \\
\text { Efficient lamps ( } 32 \text {-watt) } \\
\text { Efficient lamps ( } 32 \text {-watt) } \\
\text { Efficient lamps ( } 32 \text {-watt) } \\
\text { Efficient lamps ( } 34 \text {-watt sales) } \\
\text { Efficient lamps ( } 34 \text {-watt sales) } \\
\text { Efficient lamps ( } 34 \text {-watt storage) } \\
\text { Efficient lamps ( } 34 \text {-watt) } \\
\text { Efficient lamps ( } 34 \text {-watt) } \\
\text { Efficient lamps ( } 34 \text {-watt) } \\
\text { Efficient lamps ( } 34 \text {-watt) } \\
\text { Efficient lamps ( } 34 \text {-watt) } \\
\text { Efficient lamps ( } 34 \text {-watt) } \\
\text { Efficient lamps ( } 34 \text {-watt) } \\
\text { Efficient lamps (60-watt) } \\
\text { Eff. windows (double low-e office) } \\
\text { Eff. windows (double low-e warehouse) } \\
\text { Efficient windows (double low-e) } \\
\text { Efficient windows (double low-e) } \\
\text { Efficient windows (double low-e) } \\
\text { Efficient windows (double low-e) } \\
\text { Efficient windows (double low-e) } \\
\text { Efficient windows (double low-e) } \\
\text { Efficient windows (low-e) } \\
\text { Efficient windows (low-e) }\end{array}$ & $\begin{array}{l}\text { Control unit } \\
\text { Control unit } \\
\text { Control unit } \\
\text { Fixture } \\
\text { Fixture } \\
\text { Fixture } \\
\text { Fixture } \\
\text { Fixture } \\
\text { Fixture } \\
\text { Fixture } \\
\text { Fixture } \\
\text { Fixture } \\
\text { Fixture } \\
\text { Lamp } \\
\text { Lamp } \\
\text { Lamp } \\
\text { Lamp } \\
\text { Lamp } \\
\text { Lamp } \\
\text { Lamp } \\
\text { Lamp } \\
\text { Lamp } \\
\text { Lamp } \\
\text { Lamp } \\
\text { Lamp } \\
\text { Lamp } \\
\text { Lamp } \\
\text { Lamp } \\
\text { Lamp } \\
\text { Lamp } \\
\text { Lamp } \\
\text { Lamp } \\
\text { Lamp } \\
\text { Lamp } \\
\text { Square foot } \\
\text { Square foot } \\
\text { Square foot } \\
\text { Square foot } \\
\text { Square foot } \\
\text { Square foot } \\
\text { Square foot } \\
\text { Square foot } \\
\text { Square foot } \\
\text { Square foot }\end{array}$ & $\begin{array}{r}2 \\
2 \\
1 \\
306 \\
34 \\
816 \\
4 \\
401 \\
4 \\
36 \\
24 \\
52 \\
643 \\
4484 \\
396 \\
562 \\
15300 \\
1482 \\
172 \\
90 \\
2756 \\
96 \\
9630 \\
396 \\
4484 \\
562 \\
90 \\
96 \\
1482 \\
172 \\
2756 \\
15300 \\
9630 \\
460 \\
164 \\
410 \\
1080 \\
778 \\
9194 \\
461 \\
13613 \\
21176 \\
59252 \\
900\end{array}$ \\
\hline
\end{tabular}


TABLE C.2. (contd)

\begin{tabular}{|c|c|c|c|}
\hline $\begin{array}{c}\text { Building } \\
\text { Type }\end{array}$ & ECM Description & Units & $\begin{array}{l}\text { Units/ } \\
\text { Building }\end{array}$ \\
\hline SR & Efficient windows (low-e) & Square foot & 490 \\
\hline RE & Exhaust heat recovery (kitchen) & Unit & 2 \\
\hline RE & Heat pump water heater & Unit & 1 \\
\hline GR & Heat pump water heater & Unit & 1 \\
\hline HM & Heat pump water heater & Unit & 4 \\
\hline HM & Heat recovery from HVAC exhaust & Unit & 2 \\
\hline RE & Heat recovery from HVAC exhaust & Unit & 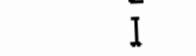 \\
\hline SO & Heat recovery from HVAC exhaust & Unit & 2 \\
\hline WA & Heat recovery from HVAC exhaust & Unjt & 1 \\
\hline HO & Heat recovery from HVAC exhaust & Unit & 4 \\
\hline GR & Heat recovery from $H V A C$ exhaust & Unit & 5 \\
\hline SR & Heat recovery from HVAC exhaust & Unit & 2 \\
\hline GR & Heat recovery to water heater & Unit & 2 \\
\hline RE & Heat recovery to water heater & Unit & 1 \\
\hline HM & High efficiency chiller & Unit & 2 \\
\hline LO & High efficiency chiller & Unit & 2 \\
\hline HO & High efficiency chiller & Unit & 2 \\
\hline GR & High efficiency heat pump & Ton & 53 \\
\hline$S R$ & High efficiency heat pump & Ton & 27.5 \\
\hline$W A$ & High efficiency heat pump & Ton & 5 \\
\hline So & High efficiency heat pump & Ton & 2 \\
\hline RE & High efficiency heat pump & Ton & 10 \\
\hline SO & Optimum start timer & Timer & 2 \\
\hline HM & Parabolic reflectors & Fjxture & 272 \\
\hline 50 & Parabolic reflectors & Fixture & 35 \\
\hline HO & Parabolic reflectors & Fixture & 2798 \\
\hline LO & Parabolic reflectors & Fixture & 3098 \\
\hline LR & Parabolic reflectors & Fixture & 908 \\
\hline SR & Parabolic reflectors & Fixture & 80 \\
\hline SC & Parabolic reflectors & Fixture & 558 \\
\hline RE & Parabolic reflectors & Fixture & 37 \\
\hline WA & Parabolic reflectors (office) & Fixture & 20 \\
\hline GR & Parabolic reflectors (sales) & Fixture & 230 \\
\hline GR & Parabolic reflectors (storage) & Fixture & 18 \\
\hline WA & Parabolic reflectors (warehouse) & Fixture & 20 \\
\hline WA & Radiant heater & $\mathrm{kW}$ & 86 \\
\hline GR & Radiant heater & kW & 32 \\
\hline SR & Radiant heater & $\mathrm{kW}$ & 11 \\
\hline WA & Reduce minimum outside air & Labor unit & 1 \\
\hline GR & Reduce minimum outside air & Labor unit & 1 \\
\hline So & Reduce minimum outside air & Labor unit & 1 \\
\hline RE & Reflective solar film & Square foot & $46 \vec{l}$ \\
\hline GR & Refrigeration anti-sweat timer & Timer & 2 \\
\hline
\end{tabular}


TABLE C.2. (contd)

Building Type

$\begin{array}{ll}\text { GR } & \text { Refrigeration case covers } \\ \text { GR } & \text { Replace elec. resistance w/ heat pump } \\ \text { WA } & \text { Replace elec. resistance w/ heat pump } \\ \text { SR } & \text { Replace elec. resistance w/ heat pump } \\ \text { RE } & \text { Replace elec. resistance w/ heat pump } \\ \text { SO } & \text { Replace elec. resistance w/ heat pump } \\ \text { GR } & \text { Roof insulation } \\ \text { HM } & \text { Roof insulation } \\ \text { WA } & \text { Roof insulation } \\ \text { LR } & \text { Roof insulation } \\ \text { SC } & \text { Roof insulation } \\ \text { SO } & \text { Roof insulation } \\ \text { LO } & \text { Roof insulation } \\ \text { HO } & \text { Roof insulation } \\ \text { RE } & \text { Roof insulation } \\ \text { SR } & \text { Roof insulation (sales) } \\ \text { SR } & \text { Roof insulation (storage) } \\ \text { RE } & \text { Strip curtains for cold space } \\ \text { GR } & \text { Strip curtains for cold space } \\ \text { LR } & \text { TB fluorescents (electronic sales) } \\ \text { SR } & \text { T8 fluorescents (electronic sales) } \\ \text { LR } & \text { T8 fluorescents (electronic storage) } \\ \text { HM } & \text { T8 fluorescents (electronic) } \\ \text { SC } & \text { T8 fluorescents (electronic) } \\ \text { LO } & \text { T8 fluorescents (electronic) } \\ \text { WA } & \text { TB fluorescents (electronic) } \\ \text { SO } & \text { T8 fluorescents (electronic) } \\ \text { HO } & \text { TB fluorescents (electronic) } \\ \text { RE } & \text { T8 fluorescents (electronic) } \\ \text { SR } & \text { T8 fluorescents (magnetic sales) } \\ \text { LR } & \text { T8 fluorescents (magnetic sales) } \\ \text { LR } & \text { T8 fluorescents (magnetic storage) } \\ H M & \text { T8 fluorescents (magnetic) } \\ \text { RE } & \text { T8 fluorescents (magnetic) } \\ \text { HO } & \text { T8 fluorescents (magnetic) } \\ \text { LO } & \text { T8 fluorescents (magnetic) } \\ \text { HO } & \text { T8 fluorescents (magnetic) } \\ \text { HM } & \text { T8 fluorescents (magnetic) } \\ \text { WO } & \text { Temperature reset for multi-zone } \\ \text { WA } & \text { Temperature reset for multi-zone } \\ & \end{array}$

Units/ Building

Linear foot $\quad 72$

Ton

Ton

Ton

Ton

Ton

Square foot

Square foot

Square foot

Square foot

Square foot

Square foot

Square foot

Square foot

Square foot

Square foot

Square foot

Linear foot

Linear foot

Fixture

Fixture

Fixture

Fixture

Fixture

Fixture

Fixture

Fixture

Fixture

Fixture

Fixture

Fixture

Fixture

Fixture

Fixture

Fixture

Fixture

Fixture

Fixture

Fixture

Reset control

Reset control

Reset control

Control unit
53

5

27.5

10

26052

24000

16375

60000

67784

2440

17000

54406

2625

11156

1969

3
24

1121

99

281

988

689

3825

24

43

1762

45

99

1121

281

988

45

1291

3825

689

24

43

6

3

24 
IABLE C.2. (contd)

\begin{tabular}{|c|c|c|c|}
\hline $\begin{array}{c}\text { Building } \\
\text { Type }\end{array}$ & ECM Description & Units & $\begin{array}{c}\text { Units/ } \\
\text { Building }\end{array}$ \\
\hline $\begin{array}{l}\text { HO } \\
\text { SC } \\
\text { GR } \\
\text { LO } \\
\text { WA } \\
\text { SO } \\
\text { RE } \\
\text { LO } \\
\text { HO } \\
\text { SO } \\
H M \\
\text { SC } \\
\text { HA } \\
\text { SR } \\
\text { LR } \\
\text { GR } \\
\text { SR } \\
\text { GR } \\
\text { LR } \\
\text { WA } \\
\text { GR } \\
\text { LR } \\
\text { WA } \\
\text { SO } \\
\text { SR } \\
\text { HM } \\
\text { SC } \\
\text { RE } \\
\text { LR } \\
\text { SR } \\
\text { SC } \\
R E \\
\text { SO } \\
\text { GR } \\
\text { WA }\end{array}$ & $\begin{array}{l}\text { Two-level switching } \\
\text { Two-level switching } \\
\text { Two-level switching } \\
\text { Two-level switching } \\
\text { Two-level switching } \\
\text { Two-level switching } \\
\text { Wall insulation } \\
\text { Wa]l insulation } \\
\text { Wall insulation } \\
\text { Wall insulation } \\
\text { Wall insulation } \\
\text { Wall insulation } \\
\text { Wall insulation (office) } \\
\text { Wall insulation (sales) } \\
\text { Wall insulation (sales) } \\
\text { Wall insulation (sales) } \\
\text { Wall insulation (storage) } \\
\text { Wall insulation (storage) } \\
\text { Wall insulation (storage) } \\
\text { Wall insulation (warehouse) } \\
\text { Water heater tank insulation } \\
\text { Water heater tank insulation } \\
\text { Water heater tank insulation } \\
\text { Water heater tank insulation } \\
\text { Water heater tank insulation } \\
\text { Water heater tank insulation } \\
\text { Water heater tank insulation } \\
\text { Water heater tank insulation } \\
\text { Water heater time clock } \\
\text { Water heater time clock } \\
\text { Water heater time clock } \\
\text { Water heater time clock } \\
\text { Water heater time clock } \\
\text { Water heater time clock } \\
\text { Water heater time clock }\end{array}$ & $\begin{array}{l}\text { Fixture } \\
\text { Fixture } \\
\text { Fixture } \\
\text { Fixture } \\
\text { Fixture } \\
\text { Fixture } \\
\text { Square foot } \\
\text { Square foot } \\
\text { Square foot } \\
\text { Square foot } \\
\text { Square foot } \\
\text { Square foot } \\
\text { Square foot } \\
\text { Square foot } \\
\text { Square foot } \\
\text { Square foot } \\
\text { Square foot } \\
\text { Square foot } \\
\text { Square foot } \\
\text { Square foot } \\
\text { Blanket } \\
\text { Blanket } \\
\text { Blanket } \\
\text { Blanket } \\
\text { Blanket } \\
\text { Blanket } \\
\text { Blanket } \\
\text { Blanket } \\
\text { Clock unit } \\
\text { Clock unit } \\
\text { Clock unit } \\
\text { Clock unit } \\
\text { Clock unit } \\
\text { Clock unit } \\
\text { Clock unit }\end{array}$ & $\begin{array}{r}360 \\
689 \\
230 \\
1590 \\
12 \\
14 \\
2191 \\
119491 \\
43428 \\
3969 \\
84254 \\
27124 \\
1547 \\
2618 \\
21564 \\
5741 \\
1600 \\
4190 \\
4105 \\
8859 \\
3 \\
4 \\
1 \\
1 \\
1 \\
6 \\
3 \\
1 \\
4 \\
1 \\
3 \\
1 \\
1 \\
1 \\
1\end{array}$ \\
\hline
\end{tabular}

$L O=$ Large Office, $S O=$ Small office, $L R=$ Large Retail,

$S R=$ Small Retail, $R E=$ Restaurant, $G R=$ Grocery, $H M=$ Hotel/Motel, $S C=$ School, $W A=$ Warehouse, $H O=$ Hospital. 


\section{REFERENCES}

United Industries Corporation (UIC). July 1987. DOE-2 Commercial Bujlding Prototype Review and Revision, Warehouse. United Industries Corp., Bellevue, Washington.

United Industries Corporation (UIC). August 1987. DOE-2 Commercial Building Prototype Review and Revision, Small office. United Industries Corp., Bellevue, Washington.

United Industries Corporation (UIC). December 1987. DOE-2 Commercial Building Prototype Review and Revision, Large Office. United Industries Corp., Bellevue, Washington.

United Industries Corporation (UIC). February 1988. D0E-2 Commercial Building Prototype Review and Revision, Hospital. United Industries Corp., Bellevue, Washington.

United Industries Corporation (UIC). March 1988. DDE-2 Commercial Building Prototype Review and Revision. Fast Food Restaurant. United Industries Corp., Bellevue, Washington.

United Industries Corporation (UIC). March 1988. DOE-2 Commercial Building Prototype Review and Revision, Hotel. United Industries Corp., Bellevue, Washington.

United Industries Corporation (UIC). March 1988. D0E-2 Commercial Building Prototype Review and Revision, Large Retail. United Industries Corp., Bellevue, Washington.

United Industries Corporation (UIC). March 1988. DOE-2 Commercial Building Prototype Review and Revision, Small Retail. United Industries Corp., Bellevue, Washington.

United Industries Corporation (UIC). June 1988, D0E-2 Commercial Building Prototype Review and Revision, Grocery. United Industries Corp., Bellevue, Washington.

United Industries Corporation (UIC). June 1988. DOE-2 Commercial Building Prototype Review and Revision, School. United Industries Corp., Bellevue, Washington. 


\section{DISTRIBUTION}

No. of

Copies

OFFSITE

12 DOE/Office of Scientific and Technical Information

10 R. W. Schultz Pacific Northwest Laboratory 2215 Bridger Drive Bozeman, MT 59715

100 . Blumhardt Bonneville Power Administration - RPED P. 0. 3621

Portiand, OR 97208
No. of

Copies

ONSITE

8 Pacific Northwest Laboratory

D. C. Kavanaugh

E. J. Stenehjem

Publishing Coordination

Technical Report Files (5) 
